\title{
Die funksie van die belydenis in die struktuur van die kerk en die betekenis daarvan vir die predikant
}

GC Velthuysen

Abstract

The function of the Confession in the structure of the church and its ministerial implications

In this paper it is argued that the church is'nt a monolithical structure but that it is constituted by various constituent elements, all of which are interdependent, interrelated and indispensable. Of these, the most important is the Confession. It constitutes the character and 'personality' of a church and as such is a constituent force in each of the other elements treated here, namely theology, the proclamation of the gospel and church-law. The minister finds himself in an ambivalent relation to the gospel. This is due to the fact that each of the other constituent elements stands in an ambivalent relation to the Confession while the minister is in relation to each of them individually as they stand in relation amongst themselves and to all of them collectively.

\section{MONOLITIESE STRUKTUUR?}

Die kerk is nie, en het nie, 'n monolitiese struktuur nie. Dit vertoon veel eerder 'n multidimensionaliteit. Anders gesê, dit het nie net een konstituerende element nie, maar verskeie.

Dit sou verder aangedui en beredeneer kon word dat hierdie elemente nie almal in dieselfde sin van die woord belangrik is nie en dat sommiges hiervan 'n prioriteit oor ander toekom. Dit is verder ook waar dat daar 'n gedurige wisselwerking tussen hierdie verskillende elemente is. Hulle vul mekaar wedersyds aan en het mekaar nodig met die gevolg dat die struktuur van die kerk nie een van hulle kan ontbeer nie.

Voordat daar breedvoerig oor die struktuur as sodanig uitgewy word, moet daar vereers duidelikheid oor die fondament waarop hierdie ganse struktuur staan, gekry word. Die fondament is uit die aard van die saak die belangrikste deel van enige struktuur, omdat dit alles dra. Ook in hierdie geval moet dit altyd bygedink word wanneer elk- 
een van die elemente van die struktuur ter sprake is. Tog kom dit nie verder direk aan die bod nie, juis omdat dit nie ' $n$ element is nie. Waarna verwys word, is natuurlik die Woord, die Heilige Skrif, as getuienis van die lewende fondament van sy kerk, Jesus Christus. Sonder hierdie fondament kan daar nie kerk wees nie en elkeen van die elemente moet in die lig van die wyse waarop hy aan die fondament verbind is, beoordeel word.

Ter wille van die argument wat in hierdie voordrag na vore gebring word, word vier sodanige konstituerende elemente van die kerklike struktuur onderskei, te wete die belydenis, die teologie, die verkondiging (meer bepaald die prediking) en die kerkorde (kerkwet volgens ons terminologie). Ons gaan nou elkeen hiervan kortliks bekyk en terselfdertyd vra na die funksie van die blydenis ten opsigte van elkeen.

\section{DIE BELYDENIS}

Die belydenis kom eerste aan die beurt. As konstituerende element is dit stellig die belangrikste bousteen in die struktuur van die kerk. Dit is immers aanduidend van die aard en karakter, van die 'persoonlikheid' van die kerk. Dit is die middel waardeur die kerk hom afgrens van die nie-kerk en valse kerk. Dit is die instrument waarmee hy hom voor die wêreld en ander kerke verantwoord. Dit is uiteindelik die aanduiding van die wyse waarop die kerk op sy fondament gebou is, asook van die ingange waarlangs die Woord in die kerk inspraak het.

Juis om hierdie rede is die belydenis die voorwaarde vir orde en geordendheid binne die kerklike struktuur. Dit dui grense aan. Dit trek riglyne. Dit dui die breë beginselraamwerk aan waarbinne die kerk homself verstaan, asook die breë lyne waarlangs hy sy optrede in die wêreld wil loods.

\section{DIE TEOLOGIE}

Die tweede element in die kerkstruktuur wat aandag verdien, is die teologie. Die teologie is die sistematiese deurdenking van die Wil in Christus deur die kerk. Die teologie is ' $n$ bedrywigheid wat uniek aan die kerk is en juis bostaande definisie dui aan waarom dit so is. Die deurdenking van die Wil van Christus is nie net 'n rasionele aangeleentheid nie en kan dit ook nooit wees nie. Dit is alreeds ' $n$ geloofswerksaamheid, want die geloofsaanvaarding dat die heil in Christus is, lê reeds op die agtergrond. 
Die teologie is verder die inherente dinamiek waardeur die kerk aan homself gestalte gee. Die resultate daarvan vind uiteindelik neerslag en uiting in wat die kerk sê en doen. Dit is waar ten opsigte van die binne-kerklike aktiwiteit van die verkondiging en ook ten opsigte van die verantwoording teenoor die wêreld.

Tussen teologie en belydenis bestaan daar ' $n$ eienaardige en as ' $t$ ware ' $n$ dubbelslagtige verkondiging. Wanneer die teoloog binne die raamwerk van die kerk met sy werk begin, aanvaar hy die belydenis as die neerlegger van grense en aanduider van die gees en aard van die beoefening van die teologie. Daarteenoor is dit sy taak as teoloog om die belydenis voortdurend aan die hand van die Woord te toets. Daarom kan daar, vir sover as wat dit die teologie betref, nie sprake wees van belydenisdwang of selfs van belydenisbinding nie. Dit sou immers beteken dat die teologie nooit sover sou kon kom as om die belydenis werklik te toets nie. Daar kan hoogstens daarvan sprake wees dat die belydenis vir die teologie breë riglyne neerlê - riglyne waarbuite die teologie somtyds doelbewus moet beweeg en wat hy juis moet bevraagteken, indien hy sy toetsingsfunksie wil uitvoer.

Die implikasies hiervan is die volgende: Al laat die teologie hom nie deur die belydenis aan bande lê nie, moet hy steeds daarvan bewus wees - moet hy steeds daarmee besig wees en, belangrikste van alles, moet hy hom steeds ten opsigte daarvan verantwoord.

\section{DIE VERKONDIGING}

'n Derde element waarna ons kyk, is die verkondiging van die kerk as die belangrikste aktiwiteit van die liturgerende gemeente. As konstituerende element is dit uiters belangrik, aangesien dit die fondament, naamlik die Woord, telkens weer teenwoordig stel en toesien dat die kerk nie daarvan losraak nie.

Die prediking kan egter nooit in totaal subjektiewe vryheid, in die sin van 'n direkte toegang tot die Woord, plaasvind nie. Met die oog op die goeie orde en getrouheid aan die aard en karakter van die kerk wat al liturgerende verkondig, sal dit steeds vanuit 'n bepaalde invalshoek moet plaasvind. Hierdie bepalende invalshoek is die belydenis en in soverre as wat dit as sodanig funksioneer, bepaal dit die inhoud van die prediking.

Die belydenis bepaal nie die inhou van die prediking omdat dit reël van die waarheid of reël van die geloof is nie. So iets sou dit moeilik kon wees, wat dit is nie geopenbaarde waarheid nie. Dit is uiteindelik 
niks anders as die resultaat van teologiese besinning en daarom is dit self in beginsel steeds hersienbaar en veranderbaar. Dit bepaal die prediking in die sin dat dit spreekreël is. Totdat dit hersien en verander word, dui dit die parameters aan waarbinne die prediking moet beweeg.

Dit beteken nie dat die liturgerende gemeente nie somtyds teen die grense van die belydenis sal aanstoot en selfs daaroorheen sal stoot nie. Dit sal onder andere gebeur omdat nie alles wat in die evangelie ter sprake kom, in die belydenis gereflekteer word nie. Die belydenis put wel uit die Skrif, maar daarmee is die Skrif nie uitgeput nie. Hierdie oorstoot óór die grense van die belydenis moet egter nie die uitgangspunt van die prediking of die liturgering wees nie. Vryheid is hier nie in orde nie en die prediking sal hom noukeurig moet neerlê by die grammatika wat deur die spreekreël neergelê is. Dit gaan hier immers ook daarom dat die kerk homself na buite bekendstel. Daarom kan dit gevolglik nie anders as dat so 'n spreke in lyn met die belydenis sal wees nie.

\section{DIE KERKORDE}

Die laaste element wat ter sprake is, is die kerkordelike - die kerkwet. Dit is die reël van orde in die kerk. Dit is die nadere selfidentifikasie van die kerk. Ook hier is daar sprake van 'n ambivalente verhouding met die belydenis; die wet is gebou op die belydenis en in die wet verbind die kerk hom aan die belydenis. Laasgenoemde is die belangrike - want dit is ineens die waarborg daarvoor dat daar werklik orde sal wees, orde op 'n vaste basis en nie volgens arbitrêre insigte nie.

\section{DIE PREDIKANT}

Die predikant is ten nouste met elkeen van hierdie konstituerende elemente gemoeid. Daarom is dit duidelik dat sy verhouding met die belydenis moeilik anders as taamlik ambivalent kan wees. Dit kan kortliks as volg beredeneer word:

$\mathrm{Hy}$ is lidmaat van die kerk. Dit is die eerste en basiese werklikheid. Hy staan dus soos alle ander lidmate wat belydenis van geloof afgelê het, in direkte verhouding tot die belydenis as konstituerende element in die struktuur van kerk-wees. Ook sy aard, karakter en persoonlikheid as 'kerk' van Christus word hierdeur bepaal. Ook hý leef en werk binne die breë beginselraamwerk wat deur die belydenis daargestel is 
en ook sy lewe in leer moet die riglyne en duidinge van die belydenis reflekteer. Gebeur dit nie, kan hy uiteraard nie meer langer lidmaat van die kerk wees nie - wat nog te sê predikant.

As lidmaat van die kerk is hy ook aan die orde van die kerk gebonde en juis daarom op 'n selfs meer statutêre wyse aan die belydenis agter die orde. Wat hierdee bedoel word, is die volgende: In artikel 1 van sy Kerkwet verklaar die Nederduitsch Hervormde Kerk dat sy belydenis in die sogenaamde formuliere van eenheid uitgedruk word. Dit is dus nie net meer ' $n$ belydenis nie - dit is wetlik vasgelê. Die predikant is gevolglik ook wetlik aan en ten opsigte van die belydenis verbind.

$\mathrm{Hy}$ is die prediker. Dit is hy wat moet verkondig. As sodanig moet hy die belydenis as spreekreël respekteer. Wanneer hy preek is hy die stem van die kerk - in ieder geval vir dié wat hom hoor. Daarom kan dit nie anders nie as dat hy die stem van die kerk nie sal verduister nie, maar sy standpunt en belydenis getrou sal reflekteer.

$\mathrm{Hy}$ is egter ook teoloog. Ook nie maar sommer 'n vryblywende teoloog nie, maar teoloog van die kerk. Dit beteken uiteraard dat hy met inagneming van die belydenis sy teologie sal beoefen en bedryf. Hy sal minstens nie anders kan nie as om die gees en aard van teologiebeoefening, soos deur die belydenis vergestalt en voorgeskryf, te volg nie.

Maar op sy skouers, soos op dié van elke ander predikant, lê die verantwoordelikheid om ter wille van die waarheid, ter wille van die geloofwaardigheid van die kerk en bowe-al ter wille van die Here van die kerk, die belydenis steeds te toets. Dit vra natuurlik afstand kritiese afstand. Dit vra dat die predikant as teoloog onder die belydenis sal uitbeweeg en daar langsaan gaan staan. Dit beteken nie dat hy daarbó sal gaan staan nie, maar in ieder geval dat hy só ver daarvan sal wegkom as wat nodig is vir kritiese toetsing aan die hand van die Woord.

Die implikasies hiervan is nie dat die predikant-teoloog ' $n$ geestelike skisofreen moet wees nie. Dit vra nie van hom om ' $n$ dubbele bestaan te voer nie; kritiese teoloog in die studeerkamer en konformerende dominee daarbuite nie. Dit vra van hom hom die vervulling van die dubbele rol wat hy kragtens sy roeping het. Hy is predikant van die kerk, en daarom daarvoor verantwoordelik dat die belydenis van die kerk weerspreek in en gereflekteer word deur sy verkondiging. Maar juis ook as predikant van die kerk is hy medeverantwoordelik vir die inhoud van die kerk se verkondiging. Omdat dit steeds die waarheid moet wees, is sy opdrag as teoloog juis om oor die waarheidsgehalte te 
waak. Daarom moet hy dit as sy hoogste verantwoordelikheid sien om daarvoor te help sorg dra dat die belydenis nie klakkeloos en blindelings gevolg sal word nie, maar dat dit as draer van die waarheid aanvaar kan word.

Die wesenlike van hierdie aangeleentheid is dat hy nie ' $n$ dienaar van die belydenis is nie, maar dienaar van die Woord. Die belydenis is vir die kerk onontbeerlik. Dit mag egter nooit 'n doel op sigself wees nie. Die belangrikste saak vir die kerk is die fondament waarop hy staan. Op hierdie fondament rig hy homself as struktuur op. Hierdie bouwerk is hoogs belangrik en krities en moet met versigtigheid aangepak word. En hy wat bou, moet mooi kyk hoe hy bou, want niemand kan ' $n$ ander fondament lê as wat reeds gelê is nie (1 Kor 3:11). In hierdie bouwerk vervul die predikant-teoloog ' $n$ wesenlik belangrike funksie. Hy moet toesien dat daar nie 'n ander fondament langs die Woord gelê word nie. Hy moet veral daarop bedag wees dat hierdie funksie nie aan die belydenis toegeken word nie. (Binne Reformatoriese kring is dit die steeds dreigende gevaar.) As mensewerk, selfs van hoogstaande gehalte, is dit nie daartoe in staan om as fondament die kerk te dra nie! Maar hy moet terselfdertyd toesien dat dit as die raamwerk, waaraan die hele res van die kerklike struktuur hang, stewig op die fondament staan. Sodoende staan die hele struktuur stewig. Sodoende bied dit ' $n$ veilige tuiste aan die kinders van die Here. 